\title{
SPENT BATTERY FLOWS, CHARACTERIZATION AND RECYCLING PROCESSES
}

\author{
N. VIECELI ${ }^{1}$, F. PEDROSA ${ }^{2}$, F. MARGARIDO ${ }^{1} \&$ C.A. NOGUEIRA ${ }^{2}$ \\ ${ }^{1}$ Center for Innovation, Technology and Policy Research-IN+, Instituto Superior Técnico, University of Lisbon. \\ ${ }^{2}$ LNEG - Laboratório Nacional de Energia e Geologia, I.P.
}

\begin{abstract}
Spent batteries are an important waste flow regarding the recovery of the contained metals motivated by economic, environmental and strategic reasons. The portable battery market is dominated by primary $\mathrm{Zn}-\mathrm{Mn}$ cells, but the market of secondary batteries are continuously growing, with particular relevance for Li-ion batteries, used in practically all electronic devices. The batteries are metal concentrates, having metal grades such as $20 \%-30 \%$ of $\mathrm{Zn}, \mathrm{Mn}, \mathrm{Co}$, Ni, depending on the battery system. These metals are specifically concentrated in the electrodes, which are the most important component of a battery. The most usual chemical forms of these metals in the electrodes are oxides or hydrated oxides, but other solid phases can be found such as metal alloys. The recycling of batteries can be done by pyrometallurgical and hydrometallurgical processes. The first one usually involves the distillation of some more volatile metals, such as $\mathrm{Zn}$ in $\mathrm{Zn}-\mathrm{Mn}$ cells and $\mathrm{Cd}$ in $\mathrm{Ni}-\mathrm{Cd}$ cells. For $\mathrm{Ni}-\mathrm{MH}$ and $\mathrm{Li}$-ion batteries, some pyrometallurgical approaches involve the melting and recovery of $\mathrm{Ni}$ or $\mathrm{Co}$, but with losses of other metals (like lithium and rare earths). The hydrometallurgical alternative allows higher metal recovery rates, as practised industrially for $\mathrm{Zn}-\mathrm{Mn}$ and Li-ion batteries. Many studies on alternative processes for recycling Li-ion batteries have been intensively carried out due to the special interest on these batteries nowadays and in the future.

Keywords: battery characterization, battery market, battery processing, recycling, spent batteries.
\end{abstract}

\section{INTRODUCTION}

Batteries are complex products with a large variety of sizes, shapes and electrochemical systems which causes serious difficulties for predicting and carrying out its valorization. As the content of metals in these devices is generally high, when compared with those in the primary resources, it gives an important economic value for recycling them, besides the benefits like environment and resource conservation. Domestic or portable-type batteries are essentially of the $\mathrm{Zn}-\mathrm{MnO}_{2}$ system and with cylindrical shape, varying from the large size Mono (D) type to the small size Micro (AAA) type [1]. Zinc-manganese batteries are of two types, saline and alkaline, and are both primary cells (not rechargeable). The other main systems are the secondary (rechargeable) batteries of the systems nickel-cadmium (Ni-Cd), nickel-metal hydride (Ni-MH) and lithium-ion ( $\mathrm{Li}$-ion). The composition of each battery type is different, but there are also some similarities between them. The knowledge of composition, morphology and other physical and chemical characteristics is an important step to develop and to apply the most convenient recycling process for each battery type, or eventually for groups of batteries. In this paper, the main types, characteristics and recycling approaches for the several battery types are presented and discussed, in order to contribute to the improvement of the recycling of this important waste stream. 


\section{BATTERY CHARACTERIZATION}

\subsection{Battery market}

Primary batteries of $\mathrm{Zn}-\mathrm{MnO}_{2}$ system (alkaline and saline) are still the most relevant accounting to more than $70 \%$ of the market share, the alkaline being clearly predominant $(60 \%)$. The saline type is now only about $12 \%$ and is continuously decreasing. The actual trend is to increase the usage of secondary batteries, mainly the Li-ion systems, and to decrease the primary battery consumption. Li-ion primary batteries constitute $2 \%$ of the market. The $\mathrm{Ni}-\mathrm{Cd}$ system is also declining. Li-ion cells represent $10 \%$ of the market and have replaced $\mathrm{Ni}-\mathrm{Cd}$ and Ni-MH batteries ( $2 \%$ and $7 \%$ of the market, respectively) in many applications due to their high energy density, high cell voltage, low auto-discharge rate and long storage life. Therefore, they have been widely used as electrochemical power source in portable equipment, such as mobile devices, laptops and cameras, and later in electric and hybrid vehicles. Other systems represent $7 \%$ of the market. Although these data are referred to Portugal, a specific country in Europe, it is expected that the distribution does not substantially change for other European countries. Nowadays, other applications for Li-ion batteries are being addressed, namely as stationary storage of renewable energies [2-5]. Later applications are no longer classified in domestic/portable class, but in industrial battery class. Nevertheless, the change in the battery market must be taken into account in order to adapt the recycling technologies and needs to the upcoming battery flows.

\subsection{Main components and general chemical composition of batteries}

The distribution of the main components of batteries is presented in Fig. 1, being the specificity of composition of each type described later.

The electrodes are the core material of the battery, where the active electrochemicals are present. The electrodes are normally pressed as powders in the form of plates, stacks or rolls (Fig.2). Nowadays, these materials are manufactured with a highly porous structure and a large surface area to provide a low internal resistance and a capability for high performance in properties such as energy/power density.

Some micrographs of battery powders morphology are shown in Fig.3. Nanoparticles are common to found in recent battery electrodes. Positive and negative electrodes are connected by an ion conductive media (the electrolyte). The active materials are supported in plates (made of steel or Ni plated steel), thin sheets (like $\mathrm{Al}$ and $\mathrm{Cu}$ foils) or simply compressed with

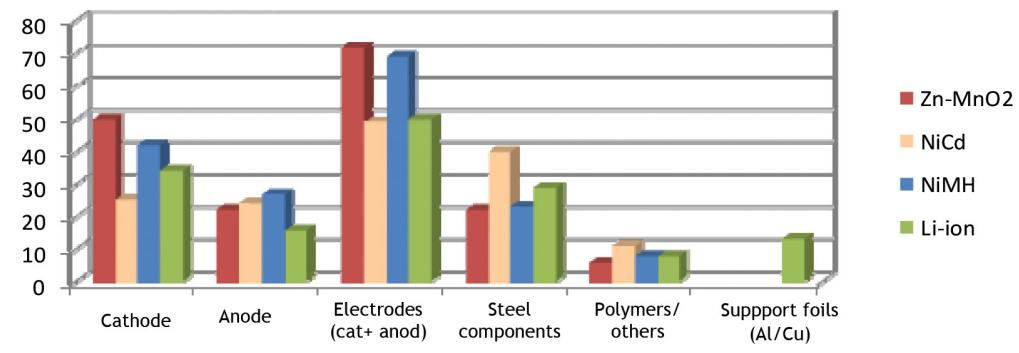

Figure 1: Distribution of main components of portable batteries. 

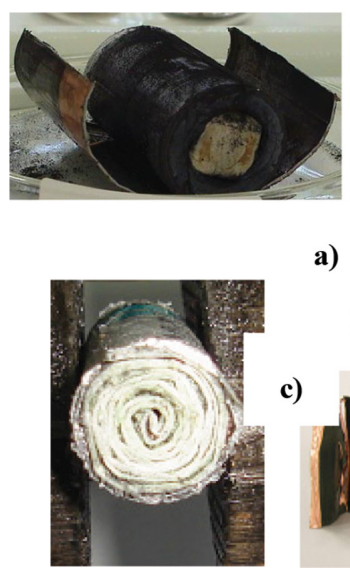

a)

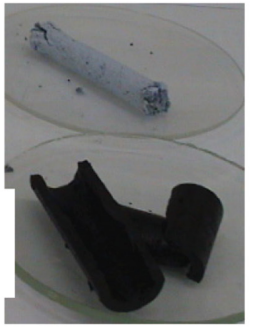

c)

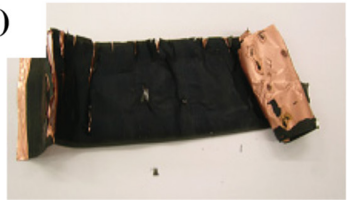

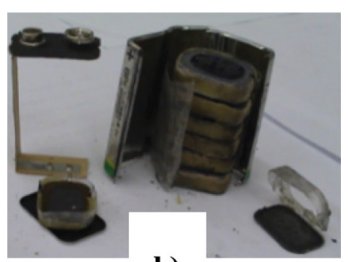

b)

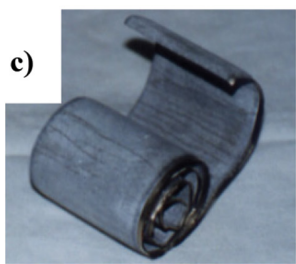

Figure 2: Several arrangements used in electrodes manufacturing: (a) compressed masses in cylindrical cells; (b) stack tablets in prismatic cells; (c) jellyroll electrodes in cylindrical cells.
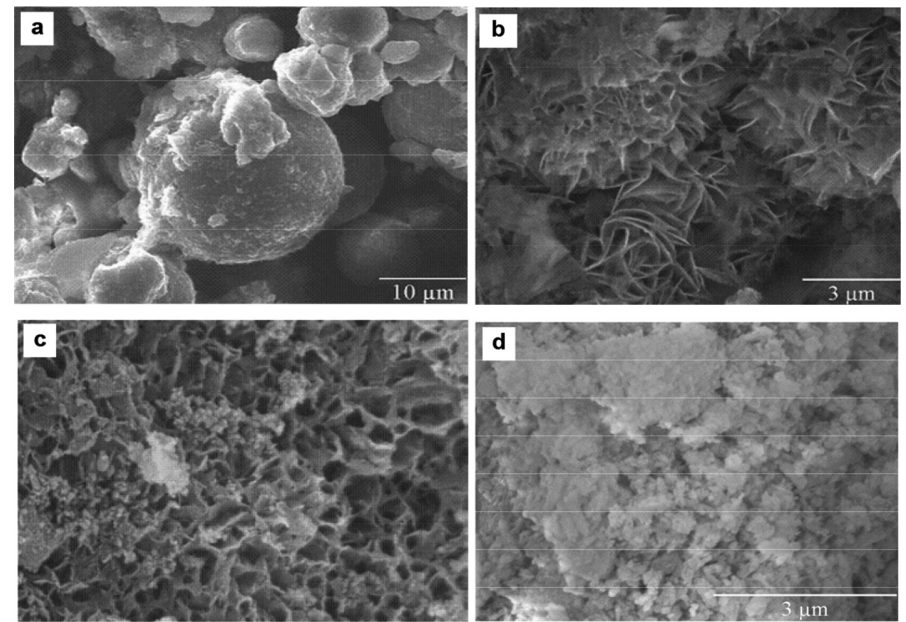

Figure 3: SEM micrographs showing electrode materials morphology of some batteries: Ni-MH (a) and (b); Alkaline (c); Ni-Cd (d).

a powder conductor (like graphite or nickel powder) to form a plaque. Besides electrodes and electrolytes, the external cans (casings) are common to all batteries, mostly composed of iron in different steel alloys or in Ni/Sn-plated steel.

Table 1 shows the typical elemental composition of spent batteries considering only the main metals for each system. All batteries are highly concentrated in metals, some of them being substantially valuable (e.g. Ni, Co, rare earths). Therefore, besides the environmental concern, economic benefits are expected from treatment of these residues. The main solid phases constituting the electrode materials are also presented in Table 1. 
Table 1: Typical composition and electrode solid phases of spent batteries.

\begin{tabular}{|c|c|c|c|c|}
\hline \multirow{2}{*}{ Element } & \multicolumn{4}{|c|}{ Elemental composition of batteries (wt\%) } \\
\hline & $\mathrm{Zn}-\mathrm{MnO}_{2}$ & $\mathrm{Ni}-\mathrm{Cd}$ & Ni-MH & Li-ion \\
\hline $\mathrm{Zn}$ & $18-25$ & - & - & - \\
\hline $\mathrm{Mn}$ & $25-30$ & - & $1.0-1.5$ & - \\
\hline $\mathrm{Fe}$ & $20-25$ & $30-45$ & $20-25$ & $25-35$ \\
\hline $\mathrm{Ni}$ & - & $20-30$ & $22-32$ & $5-10$ \\
\hline $\mathrm{Cd}$ & - & $10-15$ & - & - \\
\hline Co & - & $0.3-1.0$ & $3-4$ & $5-20$ \\
\hline $\mathrm{RE}$ & - & - & $5-10$ & - \\
\hline $\mathrm{Cu}$ & - & - & - & $5-10$ \\
\hline $\mathrm{Al}$ & - & - & $0.7-0.9$ & $3-6$ \\
\hline $\mathrm{Li}$ & - & - & - & $2-7$ \\
\hline $\begin{array}{l}\text { Main solid } \\
\text { phases in } \\
\text { electrodes }\end{array}$ & $\begin{array}{c}\mathrm{ZnO}, \mathrm{ZnOMn}_{2} \mathrm{O}_{3}, \\
\mathrm{Mn}_{3} \mathrm{O}_{4}, \mathrm{MnO}_{2}, \\
\text { graphite }\end{array}$ & $\begin{array}{c}\mathrm{Cd}(\mathrm{OH})_{2}, \\
\gamma-\mathrm{Cd}(\mathrm{OH})_{2}, \\
\mathrm{Ni}(\mathrm{OH})_{2}, \mathrm{Ni}^{\mathrm{o}}\end{array}$ & $\begin{array}{c}(\mathrm{RE}) \mathrm{Ni}_{5}, \\
\mathrm{Ni}(\mathrm{OH})_{2}, \mathrm{Ni}^{\mathrm{o}}\end{array}$ & $\begin{array}{c}\mathrm{Li}_{\mathrm{x}} \mathrm{C} \\
\mathrm{LiCoO}_{2}, \\
\text { graphite }\end{array}$ \\
\hline
\end{tabular}

$\mathrm{RE}=$ rare earths, manly $\mathrm{La}, \mathrm{Ce}$, but also traces of Pr and $\mathrm{Nd}$.

\subsection{Characterization by Battery Type}

\subsection{1 $\mathrm{Zn}-\mathrm{MnO}_{2}$ batteries}

Alkaline and saline (also called zinc-carbon) batteries are the most common portable cells of the $\mathrm{Zn}-\mathrm{MnO}_{2}$ electrochemical system. They are typically the same type of cells, varying essentially in the electrolyte used (potassium hydroxide in the first one and zinc/ammonium chloride in the second one). Although having similar chemistry, the usual assembling of these two batteries is quite different. The anode is metallic zinc, transformed to zinc oxide during its lifetime, and the cathode is $\mathrm{MnO}_{2}$, partially transformed to manganese oxides with lower valence during discharge.

Concerning the mass balance of materials [6], the cathode represents about $50 \%$ while the anode accounts to close $22 \%$. As can be seen, the electrodes are quite predominant in these cells. Iron components from casings contribute to about $22 \%$ and the remaining materials (insulators, electrode separator) are about $6 \%$. Elemental composition shows high grade of $\mathrm{Zn}$ and $\mathrm{Mn}$, typically from $20 \%$ to $30 \%$ each. In spent batteries, zincite $(\mathrm{ZnO})$ is the most probable zinc species, which is readily soluble in acid media. Several manganese oxides are probably found and their reactivity is quite different depending on the oxidation state of manganese. When considering the aqueous dissolution of $\mathrm{Mn}(\mathrm{IV})$ oxide, besides the use of an acid the addition of a reductive agent is mandatory to achieve high Mn yields. 


\subsubsection{Ni-Cd batteries}

The use of Ni-Cd batteries in domestic appliances have been drastically reduced due to environmental concerns regarding the cadmium metal. However, predictions of the overall reduction of cadmium usage in batteries failed, and $\mathrm{Ni}-\mathrm{Cd}$ cells have still usage in some applications, namely in large-scale (called 'industrial batteries') and also in some cordless tools.

The chemistry of these batteries is based on a $\mathrm{Ni}(\mathrm{OH})_{2}$ cathode and a $\mathrm{Cd}(\mathrm{OH})_{2}$ anode, which are the species present in discharge conditions. When charged, Ni(II) is oxidized to $\mathrm{NiOOH}$ and $\mathrm{Cd}$ (II) reduced to metallic cadmium. The electrodes represent about $49 \%$ of the mass balance, equally distributed by cathode and anode, steel is about $40 \%$ and the remaining $11 \%$ are plastics and other substances. Elemental chemical composition shows high metal grades, typically $20 \%-30 \% \mathrm{Ni}$ and $10 \%-15 \% \mathrm{Cd}$ [7]. Recycling of $\mathrm{Ni}-\mathrm{Cd}$ batteries is driven by the environmental control of $\mathrm{Cd}$ flows and the concern on $\mathrm{Ni}$ recovery.

\subsubsection{Ni-MH batteries}

This type of battery has gradually substituted Ni-Cd cells in portable appliances. They are based on a similar cathode $\left(\mathrm{NiOOH} / \mathrm{Ni}(\mathrm{OH})_{2}\right)$ but the anode is substantially different, constituted by metal alloys which form an hydride when charged. These metal alloys are based on $\mathrm{AB}_{5}$ and $\mathrm{AB}_{2}$ compositions. For the first type, $\mathrm{A}$ represents a rare earth and $\mathrm{B}$ a transition metal, usually based on the composition $\mathrm{LaNi}_{5}$. For the second type, less usual, $\mathrm{A}$ is a transition metal with low atomic number and $\mathrm{B}$ some transition metals with higher atomic number.

The electrode materials are the main portion of Ni-MH batteries (about 42\%), where the cathode is predominant. The steel components constituting the metallic casings and supporting grids contribute to about $23 \%$, essentially made by Ni-plated steel. Plastics, insulators and other materials represent $8 \%$ [8].

Regarding chemical composition, portable Ni-MH battery can contain $22 \%-32 \%$ of $\mathrm{Ni}$, which gives economic interest to this waste stream. The cobalt content cannot be ignored due to its commercial value. The total rare earths grade (until 5\%-7\%) is also an interesting data that should be considered. Concerning phase composition, there are essentially two types of solid phases in electrode materials: hydroxides, mainly $\mathrm{Ni}(\mathrm{OH})_{2}$ and the metal alloys, for example $\mathrm{La} / \mathrm{CeNi}_{5}$. The reactivity of these two main forms is different and should be taken into account in any process development.

\subsubsection{Li-ion batteries}

Li-ion batteries (LIBs) are the most recent and promising of all cell types. They take advantage of the high electrochemical potential of lithium. Structurally, secondary LIBs are composed of a cathode, an anode, a separator and an organic electrolyte [9]. Usually, the cathode is made from $\mathrm{Al}$ foil covered by a fine layer of powdered $\mathrm{LiMO}_{2}$, where $\mathrm{M}$ represents a transition metal, commonly Co [10], but recently also $\mathrm{Ni}$ and $\mathrm{Mn}$, and their mixtures, for example $\mathrm{LiNi}_{1 / 3} \mathrm{Co}_{1 / 3} \mathrm{Mn}_{1 / 3} \mathrm{O}_{2}$ [11], in order to improve the electrochemical performance and safety. The anode consists of a $\mathrm{Cu}$ foil, covered by a fine layer of powdered graphitic carbon, for which the lithium ions migrate forming an intercalated structure. Each electrode contains a polymeric agent (PVDF) which holds the active material particles together with the electrolyte, which consists of a Li salt, dissolved in an organic solvent (e.g. dimethyl carbonate and diethyl carbonate). During charge/discharge cycles, Li ions migrate between the anode and 
the cathode through the electrolyte. In large-scale application, other cathodes were developed for economic and safety reasons, namely the lithium-iron phosphate.

As observed for the other batteries, the electrodes represent the major proportion of the weight of the Li-ion cells, being about $50 \%$. The steel cases contribute to about $29 \%$ while plastics to $8 \%$. The remaining weight is essentially distributed by the electrode supporting foils $(5 \%$ for $\mathrm{Al}$ and $8 \%$ for $\mathrm{Cu})$.

The main element of a Li-ion portable cell is cobalt (about 5\%-20\%) which gives a special economic and strategic interest for recycling these wastes. Other constituents are lithium $(2 \%-7 \%)$, nickel (5\%-10\%), organic chemicals (near 15\%), depending on the manufacturing process [12]. In spite of being a core element of the battery performance, lithium is economically much less attractive than cobalt. However, when considering the expected boost in Li demand for electric vehicle batteries, lithium will be quickly considered a strategic metal. Then, its recovery from spent batteries should be a major concern. Regarding metals recovery from spent batteries, the reactivity of electrodes is relatively favourable. For example, using acid media in relatively low concentrations will allow substantial dissolution of $\mathrm{Li}$ and $\mathrm{Co}$ from electrode materials.

\section{PROCESSING OF SPENT BATTERIES}

The chemical treatment of batteries can be performed by pyrometallurgy or hydrometallurgy $[13,14]$. Pyrometallurgical processes are carried out in smelters which process primary resources. The furnace charge can also include secondary, resources namely batteries, normally in a small amount. So, for some types of batteries, the use of some already existing facilities can be an advantage. However, sometimes this is not possible (such as when there is mercury in the battery composition) but in some cases, a pre-treatment can be eventually done. The processes involve usually a smelting operation producing a metal stream for valorization and a slag for discharging. The hydrometallurgical processes for spent batteries are not so common. They involve a mechanical/physical treatment (shredding, separation of ferrous materials and non-metallic fractions), followed by leaching, usually in acid media, and a series of hydrometallurgical separation operations (precipitation, solvent extraction, electrowinning) to produce the valorized metals or metal compounds. The iron from case components is always a problem in aqueous processing since the dissolved $\mathrm{Fe}$ will require the introduction of more purification steps. A detailed discussion of processes for some battery types follows.

\subsection{Processes for $\mathrm{Zn}-\mathrm{MnO}_{2}$ batteries}

Several pyrometallurgical processes were developed and applied to spent $\mathrm{Zn}-\mathrm{MnO}_{2}$ batteries. These processes operate in dedicated plants $[15,16]$. An initial step of thermal treatment is normally used where the pyrolysis of plastics occurs, as well as the distillation of mercury, if it is present. The pyrometallurgical process runs with zinc volatilization and condensation as metal or oxide, to be reused. The iron and manganese can be recovered as an alloy or discharged as slag.

Industrial applications of hydrometallurgical processes are also known [17,18]. Batteries are mechanically treated and the fragments of different materials are separated by means of physical operations. The electrodes constituting the 'black mass' are therefore leached in sulfuric acid media, and zinc and manganese are recovered applying sequential and selective precipitation steps. Solvent extraction for $\mathrm{Zn} / \mathrm{Mn}$ separation was also proposed and applied for hydrometallurgical treatment of these batteries. 


\subsection{Processes for Ni-Cd batteries}

The Ni-Cd batteries were the first cell type to be recycled in dedicated plants, some decades ago. The processes were operated by some battery manufacturers allowing recovery and reuse of recycled cadmium for producing new batteries $[19,20]$. The process scheme is more or less similar to that of $\mathrm{Zn}-\mathrm{MnO}_{2}$ batteries, involving a pyrolysis step followed by cadmium distillation (volatilization and condensation) and its recovery in a pure form. Nickel can be slagged or else alloyed with iron to be potentially utilized. No evidence of cobalt recovery is addressed by these processes, although the content of this metal in these cells is not negligible. Hydrometallurgical processes were also developed but not applied to this type of batteries.

\subsection{Processes for Ni-MH batteries}

Pyrometallurgical processing of Ni-MH batteries involves smelting for nickel recovery as a metal phase. Other elements such as the rare earths are lost in the slag. So, these processes are relatively simple and objective, but the loose of important elements cannot be disregarded. The alternative hydrometallurgical approach can give a more efficient recovery of metals, but requires more steps. After mechanical processing, the metals are leached and the rare earths can be precipitated as sulfate double salt or extracted by adequate organic extractants and subsequently stripped and recovered. The residual nickel in solution can also be further recovered by another precipitation operation.

\subsection{Processes for Li-ion batteries}

Processing of Li-ion batteries for separate and recover its valuable components can involve physical and chemical steps, in sequence of eventually combined. Several operations of pretreatment can be applied, such as mechanical process, thermal treatment, mechanochemical process and dissolution process. Mechanical separation processes, such as crushing and grinding, magnetic and electrostatic separation, gravity separation, sieving, pneumatic separation, air separation and flotation, can be used to remove the external casing and release and concentrate the metallic fraction, which will be treated by hydrometallurgy or pyrometallurgy [9]. Hydrometallurgical treatment can involve several operations such as acid or alkaline leaching, bioleaching, solvent extraction, chemical precipitation and electrochemical processes [5]. Concerning industrial application, the pyrometallurgical processes are usually related to Co recovery and can be carried out in integrated smelters where other secondary resources are treated. Cobalt is melted and purified as pure metal while lithium is lost in the slag. The more recent hydrometallurgical industrial approaches allow recovery of cobalt and lithium by means of mechanical processing/deactivation, leaching and purification/precipitation operations [20]. Both approaches have advantages and disadvantages: pyrometallurgy comprises hazardous gases release, dust emission and high energy consumption; in other hand, hydrometallurgy comprises more unit operations, lower energy requirements but wastewater is produced in this case $[11,22]$.

\subsection{New developments for Li-ion batteries}

Recently, several studies concerning hydrometallurgical methods using organic acids rather than mineral acids have been developed. Using succinic acid as leaching agent and $\mathrm{H}_{2} \mathrm{O}_{2}$ as 
reductant in optimized conditions allowed leaching about $100 \%$ of Co and $96 \%$ of $\mathrm{Li}$ [23]. Almost complete dissolution of $\mathrm{Li}$ and $\mathrm{Co}$ from spent LIBs was reached using a mixture of citric acid and ascorbic acid [2]. Citric acid and D-glucose were used as leaching reagent and reductant in the leaching for metal extraction from cathode materials [24]. Leaching of active materials from spent LIBs using citric acid and $\mathrm{H}_{2} \mathrm{O}_{2}$ was investigated by Fan et al. [25]. A leaching process of $\mathrm{LiCoO}_{2}$ using oxalic acid without hydrogen peroxide was study by Zeng et al. [26] and about $98 \%$ and $97 \%$ of $\mathrm{Li}$ and Co recovery were reached, respectively. Other alternative leaching process was studied by $\mathrm{Ku}$ et al. [27] from treated cathode active materials, from a commercial LIB pack of hybrid electric vehicle, using ammoniacal agents and it was verified that $\mathrm{Co}$ and $\mathrm{Cu}$ can be completely leached while $\mathrm{Mn}$ and $\mathrm{Al}$ are hardly leached and Ni has a moderate leaching efficiency.

A revision of the separation and purification of lithium by solvent extraction and supported liquid membrane was stated by Swain [28], who considered that research in this field still need to be conducted, given the drawbacks and lack of research on these topics. Alternatively, supercritical fluids were considered for the leaching of cobalt from LIBs by Bertuol et al. [9], using $\mathrm{CO}_{2}, \mathrm{H}_{2} \mathrm{SO}_{4}$ and $\mathrm{H}_{2} \mathrm{O}_{2}$ as reagents and a recovery of $96 \%$ of Co was achieved by electrowinning. A mechanochemical approach to recover Li and Co from spent LIBs was studied by Wang et al. [29] and in the process lithium cobalt oxide was co-grinded with different additives and $98 \%$ of $\mathrm{Co}$ and $99 \%$ of $\mathrm{Li}$ were recovered by water leaching.

Researches concerning the use of bioleaching of spent lithium batteries are scarce [5], but some studies have recently been reported. Bioleaching of metals from spent LIBs was investigated by Xin et al. [30] and high extractions (more than 95\%) of four valuable elements were achieved. Bioleaching of Co from spent LIBs was also studied by Zeng et al. [31], who achieved a dissolution of about $99 \%$ using copper ions as catalyst, enhancing the oxidation rate of $\mathrm{LiCoO}_{2}$ and the leaching of cobalt. The bioleaching of spent LIBs at different pulp densities was investigated by Niu et al. [32], who achieved a Li and Co extraction of 89 and 72\%, respectively.

According to Ordeñez et al. [5], most of the researches regarding the recycling of spent LIBs focus on the recovery of metals, given their scarcity and cost, but there are few studies on the recovery of graphite and electrolyte, for example. According to Zeng et al. [33], most of these researches are still in pilot or laboratory scale and most processes are based on hydrometallurgical chemistry and, more focus is given on recycling and recovery than reuse and dismantling. In this context, some methods to separate materials from LIBs have been recently studied. Spouted bed elutriation was investigated by Bertuol et al. [34]. A physical pre-treatment for the separation of the cathode active materials from the Al foil using $\mathrm{N}$-methyl-2-pyrrolidone as ultrasonic solvent and calcination was tested by Yang et al. [35]. A method of melting the PVDF binder to separate the $\mathrm{Al}$ foil and cathode material from spent LIBs was investigated by Zeng et al. [36].

Several studies concerning the development of novel and alternative electrode materials have also been performed. Manganese-based layer-structured materials, such as $\mathrm{Li}\left[\mathrm{Ni}_{1 / 3} \mathrm{Co}_{1 / 3} \mathrm{Mn}_{1 / 3}\right] \mathrm{O}_{2}$ and $\mathrm{Li}\left[\mathrm{Ni}_{1 / 2} \mathrm{Mn}_{1 / 2}\right] \mathrm{O}_{2}$, are one of the most promising alternative materials for the cathode material [22,35]. These new developments, as it was mentioned before, aim to improve the safety and performance characteristic of LIBs but can lead to new challenges for recycling, given the potential complexity of the waste stream.

\section{CONCLUSION}

The composition, characterization and processing of spent batteries are presented and discussed. The market of portable batteries is composed of primary and secondary cells, from 
which the primary Zn-Mn cells are predominant (about 70\%), the remaining being essentially the secondary cells of the systems Ni-Cd, Ni-MH and Li-ion. Li-ion batteries have nowadays a substantial growing due to their application in portable electronic devices. The high grade of metals in battery composition (like $\mathrm{Co}, \mathrm{Ni}, \mathrm{Li}, \mathrm{Zn}, \mathrm{Mn}$, rare earths), some of them valuable and critical, confers to these an economic and even strategic interest. Several recycling processes for recovering the metals from the spent batteries have been developed and applied. Due to their special interest, new studies and developments for the recycling of Li-ion batteries have been extensively performed in order to increase the recovery yields of the contained metals.

\section{ACKNOWLEDGEMENTS}

The author N. Vieceli acknowledges the doctorate grant ref. 9244/13-1 supplied by CAPES Foundation, Ministry of Education of Brazil.

\section{REFERENCES}

[1] Linden, D., (Chapters 8 and 10). Handbook of Batteries, 2nd ed., McGraw-Hill Inc.: New York, 1995.

[2] Nayaka, G.P.,Manjanna, J., Pai, K.V., Vadavi, R., Keny, S.J. \& Tripathi, V.S., Recovery of valuable metal ions from the spent lithium-ion battery using aqueous mixture of mild organic acids as alternative to mineral acids. Hydrometallurgy, 151, pp. 73-77, 2015.

[3] Castillo, S., Ansart, F., Laberty-Robert, C. \& Portal, J., "Advances in the recovering of spent lithium battery compounds". Journal of Power Sources, 112(1), pp. 247-254, 2002. http://dx.doi.org/10.1016/S0378-7753(02)00361-0

[4] Chen, X., Zhou, T., Kong, J., Fang, H. \& Chen, Y., Separation and recovery of metal values from leach liquor of waste lithium nickel cobalt manganese oxide based cathodes. Separation and Purification Technology, 141, pp. 76-83, 2015. http://dx.doi.org/10.1016/j.seppur.2014.11.039

[5] Ordoñez, J., Gago, E.J. \& Girard,A., Processes and technologies for the recycling and recovery of spent lithium-ion batteries. Renewable and Sustainable Energy Reviews, 60, pp. 195-205, 2016.

[6] http://dx.doi.org/10.1016/j.rser.2015.12.363

[7] Cabral, M., Pedrosa, F., Margarido, F. \& Nogueira, C.A., End-of-life Zn-MnO 2 batteries: electrode materials characterization. Environmental Technology, 34(10), pp. 1283-1295, 2013. http://dx.doi.org/10.1080/09593330.2012.745621

[8] Nogueira, C.A. \& Margarido, F., Chemical and physical characterization of electrode materials of spent sealed Ni-Cd batteries. Waste Management, 27(11), pp. 1570-1579, 2007. http://dx.doi.org/10.1016/j.wasman.2006.10.007

[9] Cabral, M., Margarido, F. \& Nogueira, C.A., Characterisation of spent Ni-MH batteries. Materials Science Forum, 730, pp. 569-574, 2013.

[10] Bertuol, D.A., Toniasso, C., Jimenez, B.M., Meili, L., Dotto, G.L., Tanabe, E.H. \& Aguiar, M.L., Application of spouted bed elutriation in the recycling of lithium ion batteries. Journalof Power Sources, 275, pp. 627-632, 2015. http://dx.doi.org/10.1016/j.jpowsour.2014.11.036 
[11] Li, L., Dunn, J.B., Zhang, X.X., Gaines, L., Chen, R.J., Wu, F. \& Amine,K.,Recovery of metals from spent lithium-ion batteries with organic acids as leaching reagents and environmental assessment. Journalof Power Sources, 233, pp. 180-189, 2013. http://dx.doi.org/10.1016/j.jpowsour.2012.12.089

[12] Chen, X., Chen, Y., Zhou, T., Liu, D., Hu,H. \& Fan, S., Hydrometallurgical recovery of metal values from sulfuric acid leaching liquor of spent lithium-ion batteries. Waste Management, 38, pp. 349-356, 2015. http://dx.doi.org/10.1016/j.wasman.2014.12.023

[13] Kang, J., Senanayake, G., Sohn, J. \& Shin, S.M., Recovery of cobalt sulfate from spent lithium ion batteries by reductive leaching and solvent extraction with Cyanex 272. Hydrometallurgy, 100(3-4), pp. 168-171, 2010. http://dx.doi.org/10.1016/j.hydromet.2009.10.010

[14] Espinosa, D.C.R., Bernardes, A.M. \& Tenório, J.A.S., An overview on the current processes for the recycling of batteries. Journalof Power Sources, 135, pp. 311-319, 2004. http://dx.doi.org/10.1016/j.jpowsour.2004.03.083

[15] Sayilgan, E., Kukrer, T., Civelekoglu, G., Ferella, F., Akcil, A., Veglio,F. \& Kitis, M., A review of technologies for the recovery of metals from spent alkaline and zinc-carbon batteries.Hydrometallurgy, 97, pp. 158-166, 2009. http://dx.doi.org/10.1016/j.hydromet.2009.02.008

[16] Beck, M., Batrec: recovering metals.Recycling International, pp. 24-27, 2004.

[17] Vollrath, K., Battery recycling in Europe: confusion and high costs. Recycling International, pp. 18-23, 1999.

[18] Frías, C., Martín, D., Díaz, G., Falgueras, J. \& Baylina, V., Highlights of domestic battery recycling plant based on the modified Zincex process sfter five years successful operation. Proceeding of the REWAS 2004-Global Symp. on Recycling, Waste Treatment and Clean Technology, vol III, eds. I. Gaballah, B. Mishra, R. Solcjzahal \& M. Tifnaka, TMS: Warredale, USA and INASMET: S. Sebastián, Spain, pp. 2299-2308.

[19] Tedjar, F., Recycling used electric cells by hydrometallurgical treatment, Int Patent Appl. WO 021708 A3, March 13, 2003.

[20] Linck, F., SNAM company update and recycling service.Proceedings of the 4th International Battery Recycling Congress, Hamburg: Germany, 1998.

[21] Bärring, N.E., Recycling of nickel-cadmium batteries and process wastes - processes and operations of the new SAB NIFE plant. Proceeding of 4th Internatonal Cadmium Conference, eds. D. Wilson \& R.A. Volfre, Intern. Cadmium Assoc.: Brussels, pp. 58-60, 1983.

[22] Tedjar, F. \& Foudraz, J.C., Method for the mixed recycling of lithium-based anode batteries and cells.Int. Patent Appl. WO 101564, October 26, 2010.

[23] Meshram, P., Pandey, B.D. \& Mankhand, T.R., Extraction of lithium from primary and secondary sources by pre-treatment, leaching and separation: a comprehensive review. Hydrometallurgy, 150, pp. 192-208, 2014. http://dx.doi.org/10.1016/j.hydromet.2014.10.012

[24] Li, L., Qu, W., Zhang, X., Lu, J., Chen, R., Wu, F. \& Amine, K., Succinic acid-based leaching system: A sustainable process for recovery of valuable metals from spent Li-ion batteries.Journalof Power Sources,282, pp. 544-551, 2015.

http://dx.doi.org/10.1016/j.jpowsour.2015.02.073

[25] Chen, X., Fan, B., Xu, L., Zhou, T. \& Kong, J., An atom-economic process for the recovery of high value-added metals from spent lithium-ion batteries, Journal of the Cleaner Production,112, pp. 3562-3570, 2016. http://dx.doi.org/10.1016/j.jclepro.2015.10.132 
[26] Fan, B., Chen, X., Zhou, T., Zhang, J. \& Xu, B., A sustainable process for the recovery of valuable metals from spent lithium-ion batteries.Waste Management\& Research,pp. $1-8,2016$. http://dx.doi.org/10.1177/0734242x16634454

[27] Zeng, X., Li,J. \& Shen, B., Novel approach to recover cobalt and lithium from spent lithium-ion battery using oxalic acid. Journal of Hazardous Materials,295, pp. 112-118, 2015. http://dx.doi.org/10.1016/j.jhazmat.2015.02.064

[28] Ku, H., Jung, Y., Jo, M., Park, S., Kim, S., Yang, D., Rhee, K., An, E., Sohn, J. \& Kwon, K., Recycling of spent lithium-ion battery cathode materials byammoniacal leaching. Journal of Hazardous Materials, 313, pp. 138-146, 2016. http://dx.doi.org/10.1016/j.jhazmat.2016.03.062

[29] Swain, B., Separation and purification of lithium by solvent extraction and supported liquid membrane, analysis of their mechanism: a review.Journal of Chemical Technology andBiotechnology, 2016.

[30] Wang, M., Zhang, C. \& Zhang, F.,An environmental benign process for cobalt and lithium recovery from spent lithium-ion batteries by mechanochemical approach. Waste Management, 51, pp. 239-244, 2016. http://dx.doi.org/10.1016/j.wasman.2016.03.006

[31] Xin, Y., Guo, X., Chen, S., Wang, J., Wu, F. \& Xin, B., Bioleaching of valuable metals $\mathrm{Li}, \mathrm{Co}, \mathrm{Ni}$ and $\mathrm{Mn}$ from spent electric vehicle Li-ion batteries for the purpose of recovery.Journal of Cleaner Production, 116, pp. 249-258, 2016. http://dx.doi.org/10.1016/j.jclepro.2016.01.001

[32] Zeng, G., Deng, X., Luo, S., Luo, X. \& Zou, J., A copper-catalyzed bioleaching process for enhancement of cobalt dissolution from spent lithium-ion batteries.Journal of Hazardous Materials, 199-200, pp. 164-169, 2012. http://dx.doi.org/10.1016/j.jhazmat.2011.10.063

[33] Niu, Z., Zou, Y., Xin, B., Chen, S., Liu, C. \& Li, Y., Process controls for improving bioleaching performance of both $\mathrm{Li}$ and $\mathrm{Co}$ from spent lithium ion batteries at high pulp density and its thermodynamics and kinetics exploration, Chemosphere, 109, pp. 92-98, 2014. http://dx.doi.org/10.1016/j.chemosphere.2014.02.059

[34] Zeng, X., Li, J. \& Singh, N., Recycling of spent lithium-ion battery: a critical review. Critical Reviews in Environmental Science and Technology, 44, pp. 1129-1165, 2014. http://dx.doi.org/10.1080/10643389.2013.763578

[35] Bertuol, D.A., Machado, C.M., Silva, M.L., Calgaro, C.O., Dotto, G.L. \& Tanabe, E.H., Recovery of cobalt from spent lithium-ion batteries using supercritical carbon dioxide extraction.Waste Management, 51, pp. 245-251, 2016. http://dx.doi.org/10.1016/j.wasman.2016.03.009

[36] Yang, L., Xi, G. \& Xi, Y., Recovery of Co, Mn, Ni, and Li from spent lithium ion batteries for the preparation of $\mathrm{LiNi}_{\mathrm{x}} \mathrm{Co}_{\mathrm{y}} \mathrm{Mn}_{\mathrm{z}} \mathrm{O}_{2}$ cathode materials Li.Ceramics International, 41, pp. 11498-11503, 2015. http://dx.doi.org/10.1016/j.ceramint.2015.05.115

[37] Zeng, X. \&Li, J., Innovative application of ionic liquid to separate Al and cathode materials from spent high-power lithium-ion, batteries.Journal of Hazardous Materials, 271, pp. 50-56, 2014. http://dx.doi.org/10.1016/j.jhazmat.2014.02.001 